\title{
Correction to: Fulvestrant-Based Combination Therapy for Second-Line Treatment of Hormone Receptor-Positive Advanced Breast Cancer
}

\author{
Sarah Sammons $^{1}$ • Noah S. Kornblum ${ }^{2}$ - Kimberly L. Blackwell ${ }^{3,4}$
}

Published online: 8 December 2018

(C) The Author(s) 2018

\section{Correction to: Targeted Oncology \\ https://doi.org/10.1007/s11523-018-0587-9}

The article Fulvestrant-Based Combination Therapy for Second-Line Treatment of Hormone Receptor-Positive Advanced Breast Cancer, written by Sarah Sammons, Noah S. Kornblum and Kimberly L. Blackwell, was originally published electronically on the publisher's internet portal (currently SpringerLink) on 22 August 2018 without open access.

With the author(s)' decision to opt for Open Choice the copyright of the article changed on 08 December 2018 to (C) The Author(s) 2018 and the article is forthwith distributed under the terms of the Creative Commons AttributionNonCommercial 4.0 International License (http:// creativecommons.org/licenses/by-nc/4.0/), which permits any noncommercial use, duplication, adaptation, distribution and reproduction in any medium or format, as long as you give appropriate credit to the original author(s) and the source, a link is provided to the Creative Commons license and any changes made are indicated.

Open Access This article is distributed under the terms of the Creative Commons Attribution-NonCommercial 4.0 International License (http:// creativecommons.org/licenses/by-nc/4.0/), which permits any noncommercial use, distribution, and reproduction in any medium, provided you give appropriate credit to the original author(s) and the source, provide a link to the Creative Commons license, and indicate if changes were made.

The online version of the original article can be found at https://doi.org/ 10.1007/s11523-018-0587-9

Kimberly L. Blackwell

kimberly.blackwell@duke.edu

Sarah Sammons

sarah.sammons@duke.edu

Noah S. Kornblum

nkornblu@montefiore.org

1 Duke University Medical Center, Durham, NC, USA

2 Montefiore Einstein Center for Cancer Care, Bronx, NY, USA

3 Department of Medicine, Duke University Medical Center, Durham, NC 27710, USA

4 Present address: Eli Lilly and Company, Indianapolis, IN 46285, USA 